\title{
Land Use Changes Resulting from Construction of Deduru Oya Reservoir and Its' Impacts on Livelihood
}

\author{
S.M.L.D. Samarakoon ${ }^{*}$, N.D.K. Dayawansa ${ }^{1}$ and E.R.N. Gunawardena ${ }^{1}$ \\ Postgraduate Institute of Agriculture \\ University of Peradeniya \\ Sri Lanka
}

\begin{abstract}
Construction of a large dam is one of the major economic and development activities that change the existing land use patterns in an area. The major visible impact of dam construction is the inundation of important land uses/land cover in the reservoir area. This study was conducted to assess the land use/ land cover changes as the result of DeduruOya reservoir construction. Multi temporal satellite images acquired through Google earth were used to identify the land use/ land cover of the reservoir area before and after dam construction. In addition, land use/ land cover changes in a $100 \mathrm{~m}$ buffer zone from the reservoir were also evaluated. A total of approximately 1178 ha land was inundated by water which included $40 \%$ of paddy, 30\% of coconutand $27 \%$ of forest lands. The loss of paddy production per year due to this inundation was $5,144 \mathrm{~kg}$ per displaced family according to the analysis creating Rs. 19.81 million of net income loss annually to the country. The economic loss from coconut land was Rs. 64.60 million per year. The economic loss per family as a result of paddy and coconut production foregone is, therefore Rs.144,240/year. Since their food security and income seemed to have been affected severely due to the reservoir construction, the authorities are required to address the livelihood changes of resettled population and make remedial measures as early as possible.The study suggests a comprehensive assessment of the impacts on people due to physical and livelihood displacement.
\end{abstract}

Keywords: Deduru Oya Dam, Land use change, Social impacts

\section{INTRODUCTION}

Land cover is known as the physical material exists on the earth surface that confined to describe both natural and man-made features (Di Gregorio and Jansen, 2000). Land use is basically a socio-economic description of the land that includes areas used for residential, industrial or commercial purposes, for farming or forestry, for recreational or conservation purposes (European Communities, 2001).Land use/ land cover play an important role in hydrology as they can control many hydrological processes including evapotranspiration, surface runoff, infiltration as well as soil erosion. Hence, changes to the natural land use/ land cover can bring adverse impacts on land and water resources in an area. Dams are constructed for multiple benefits including storing water for irrigation, domestic and industrial use, hydropower generation, flood control etc. As a consequence of dam building to store water, the entire land use and land cover pattern of the area change remarkably due

\footnotetext{
1 Department of Agricultural Engineering, University of Peradeniya, Sri Lanka

* Author for correspondence:lakminidulangika@gmail.com
} 
to inundation, reservations and for other infrastructure development activities (Tilt et al., 2008). People who live in that area will be relocated, and the land cover in that area will be cleared prior to the reservoir construction (Sahoo et al., 2014). Reservoir inundates former floodplains and riparian areas of the watershed. Fertile bottomland soil will be inundated, riparian corridors for animal movement will be blocked and the terrestrial lands could be inundated permanently or intermittently. Therefore, it is clear that the major visible impact of dam construction to the upstream is the inundation of existing land use/ land cover of the area. In addition to inundation of forests which leads to deforestation and environmental degradation, a new reservoir can lead to flood human settlements, crop lands and plantations in the area that result negative impacts on social behaviour of people and their livelihood. Groundwater and hydraulic pattern of the area related changes also can make significant impacts after a dam construction (Tilt et al., 2008).

Criticism for the Sardar Sarovar dam projects in the Narmada river basin in India have been aroused as a result of displacement of 45245 families and inundation of 13000 ha of forest lands in the area (Sahoo et al., 2014). There are similar kind of experience with the Lesotho highlands water project in Lesotho and South Africa. Losing access for potable water and natural springs, decreased access to wild food and herbs, losing access to forest and wooded area due to inundation and losing their best arable lands to inundation have led to increase protests against the project (Tilt et al., 2008). Rural areas adjacent to Manwan dam, China were significantly affected economically due to the dam construction. Paddy fields are highly valued land types in China that supply staple grain crop. Paddy lands to non-irrigated fields ratio that was 6:4 has changed to 4:6 after the dam construction. That has decreased the rice yield in the area and pushed farmers to grow other dry land crops such as maize and sugar cane with a significant drop of income (Tilt et al., 2008).

Studies have shown that $13.7 \%$ of the paddy lands and $15.6 \%$ of the coconut lands have lost in the Victoria reservoir area after construction of the Victoria dam in Sri Lanka (Wijesundara and Dayawansa, 2011). It has inundated 1925 hectares, including paddy and coconut lands and nearly $29 \mathrm{~km}$ of roads. As a result of these changes, the cultivation patterns, human settlements and natural landscape including flora and fauna of the region have formed new trends to the culture and the landscape than before (Wijesundara and Dayawansa, 2011). Similar experiences have been reported with the Kotmale Dam in Sri Lanka, which has dwindled down the tea cultivation to $43.69 \%$ (24955.6 ha) from $56.21 \%$ (32108.9 ha) in 1956, of the total area of upper Kotmale catchment after the Dam construction (Wijethunga Bandara, 2013). As a result, especially small holder tea planters have faced difficulties. Similarly, there were more than 20,000 people affected by Katse Dam in Lesotho, losing their homes, farmland or the use of communal grazing lands due to the dam construction (Hoover, 2000).

Rice farmers in Kaltota irrigation scheme imposed a restriction in the freedom of water use for cultivation during the dry seasons of the year after constructing the Samanalawewa reservoir in the upstream. The purpose of the reservoir was hydropower generation and the project introduced a compensation method for affected farmers to not to cultivate which created another set of social conflicts later (Aheeyar et al., 2008).

However, land use changes due to dam construction also have many positive impacts towards human and ecosystem. Other than the direct aims of large dams, water storage will enhance the groundwater recharge of the area and minimize drought events that are possible mostly to the upstream area. This study focuses on addressing the impacts of land use changes due to large dam projects, taking Deduru Oya reservoir project as an example. 


\section{OBJECTIVE}

The objective of this study was to identify the changes on land use and possible consequences occurred in Deduru Oya reservoir area as the result of dam construction.

\section{STUDY AREA}

This study was conducted on Deduru Oya reservoir and its surroundings. Deduru Oya is the fourth largest river in the country and originates from the western slopes of Kandy-Matale hills. The river annually discharges more than $1000 \mathrm{MCM}$ of water to the sea. The basin area falls under two climatic zones: wet and intermediate, and its sub groups (Somarathne, et al., 2003). Kimbulwana Oya, Hakwatuna Oya and Maguru Oya are the major tributaries of Deduru Oya stream. The reservoir is constructed at the middle reaches of the river, within $\mathrm{IL}_{3}$ agro ecological region and is located in Kurunegala district (Figure 1).

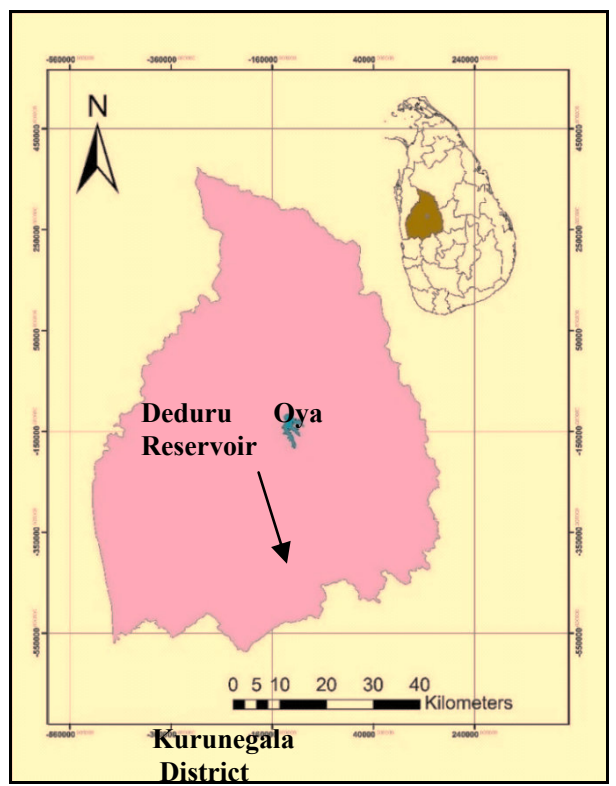

Fig. 1. Location of the Study Area within the Kurunegala District

The main aims of the reservoir are to increase the cropping intensity of this scheme to $150 \%$ and to establish a $1.5 \mathrm{GW}$ power plant. It is expected to cultivate about 11115 ha of new lands from the established reservoir (Centre for Environmental Studies - UOP, 2003).

Reservoir is located in about 300 meters upstream of the existing Ridi Bendi Ella anicut and the dam is an earth filled type. As pre calculated by the Department of Irrigation, the full supply level of the reservoir is $70 \mathrm{~m}$ MSL with an inundation area of 1400 ha. Storage capacity of the reservoir has estimated as $75 \mathrm{MCM}$ (Irrigation Department, 2001). The International Commission of Large Dams (ICOLD), defines any dam above $15 \mathrm{~m}$ in height that measured from the lowest point of foundation to the top as large dams. Dams between 10 and $15 \mathrm{~m}$ in height also falls into this category only if crest length is over $500 \mathrm{~m}$ or spillway discharge over $2000 \mathrm{~m}^{3} \mathrm{~s}^{-1}$ or reservoir capacity is more than $1 \mathrm{MCM}$ (ICOLD, 2015). Accordingly, Deduru Oya reservoir is considered as a large dam. 
The reservoir was commissioned on $22^{\text {nd }}$ November, 2014 (Irrigation Department, 2014) and the reservoir had spilled two times after the filling in December, 2014 and in November, 2015 (Santhiago, 2014; Hannan, 2015). Currently, construction of irrigation structures has been completed to convey irrigation water to the command area by both Right Bank and Left Bank Canals and the power plant is under construction.

\section{METHODOLOGY}

A multi temporal analysis was carried out to study the land use change of the study area due to the dam construction. Two multispectral Quick Birdsatellite images of the study area in 2010 October (before the reservoir construction) and 2016 February (After completing the reservoir construction) were used for the analysis (Pixel size of $2.88 \mathrm{~m}$ ). ArcGIS 10.2 software was used for GIS analysis.

A satellite image of the Deduru Oya reservoir area in 2016 - February was downloaded from the Google Earth and geo-referenced for use as the base map. Reservoir boundary was digitized using the image. A buffer zone for the reservoir was also demarcated considering $100 \mathrm{~m}$ of reservation area. Then 2010 October satellite image of the same area was used to identify the early land use pattern within the inundated area and the reservation area of the reservoir. The two digitized data layers were compared. Land use information were extracted in five land cover classes as paddy lands, forests, coconut lands, bare lands and water. Road network data were also gathered in addition to land uses.

After two temporal data layers were created, they were compared using GIS techniques to identify the changes that had occurred in the area due to dam construction and inundation. Subsequently the impacts of land use change on agricultural production and on displaced persons were assessed.

\section{RESULTS AND DISCUSSION}

\section{Land use change in the inundated area}

Land use/ land cover of the inundated area previously contained paddy lands, coconut lands, and forests as the major land uses (Figure 1 and Table 1). Largest extent of land in the region was consisted of paddy lands (39.87\%) followed by coconut lands $(31.44 \%)$ and it is clear that this area was primarily an agricultural area. According to the data, total paddy cultivation area that has inundated was 469.36 ha. Coconut and forests areas were 370.15 ha and 326.28 ha respectively (Table 1) which also had converted to water and lost after reservoir establishment. In addition to the main land uses, small water bodies and bare lands have also gone under inundation. Road network also has been affected by inundation. The length of the total road network that was inundated is approximately $11.256 \mathrm{~km}$. 
Table 1. Land use of the area before inundation (2010-October)

\begin{tabular}{lcc}
\hline $\begin{array}{l}\text { Type of Land Use / } \\
\text { Land Cover }\end{array}$ & $\begin{array}{c}\text { Land area in 2010- } \\
\text { October (ha) }\end{array}$ & \% of Total Area \\
\hline Paddy land & 469.36 & 39.87 \\
Coconut land & 370.15 & 31.44 \\
Forest & 326.28 & 27.71 \\
Bare land & 11.03 & 0.94 \\
Water tank & 0.47 & 0.04 \\
\hline Total & 1177.28 & 100.00 \\
\hline
\end{tabular}

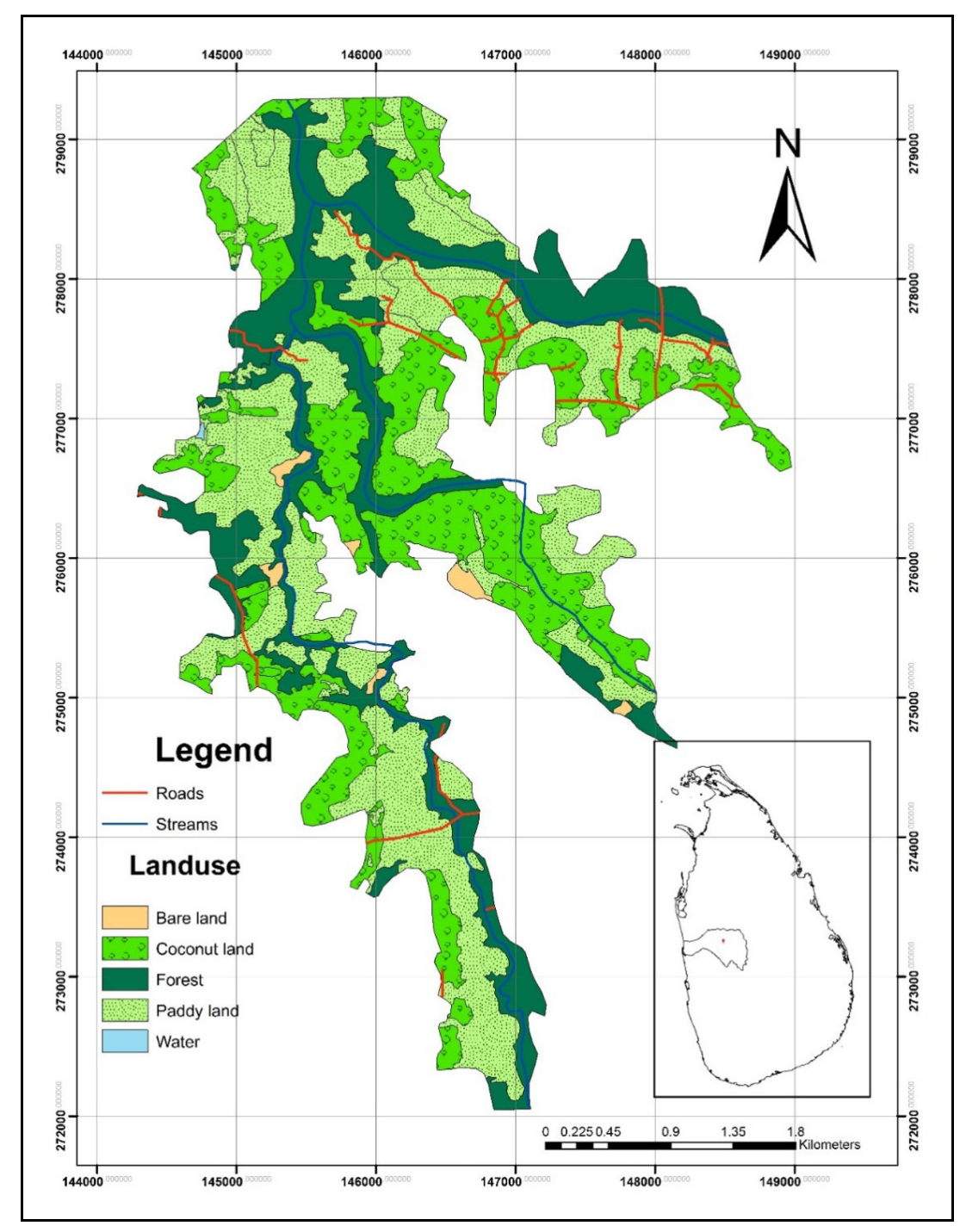

Fig. 2. Land use map of the reservoir area in 2010 (October) 


\section{Land use change in the buffer zone area of the reservoir}

Reservation area or a buffer zone can be defined as areas outlying to a specific protected area (reservoir in this context) where the resource use restrictions and special development measures undertaking to conserve the value of that area. Within a buffer zone, the use on existing natural resources may be legally or customarily restricted so as to create a transition belt (Survey Department, 2014).

According to the guidelines of the Survey Department of Sri Lanka, there are no separate reservations identified for reservoirs, but the boundary should be taken at least $5 \mathrm{~m}$ and for important reservoirs (the conditions to be an important reservoir has not defined) $20 \mathrm{~m}$ above Full Supply Level (FSL). However, there should be reservations for irrigation channels except 'wan ela' or 'pita ela' which run to waste and do not irrigate (Survey Department, 2014).

A $100 \mathrm{~m}$ wide buffer zone was taken to analysis in the study assuming the contour line of $2 \mathrm{~m}$ above the FSL is located $100 \mathrm{~m}$ away from the reservoir boundary because the reservoir is located in the IL3 agro ecological region, and the area is having an undulating terrain.

Land use/ land cover in the buffer zone before and after the dam construction was compared to identify the changes occurred (Table 2). According to the analysis, both paddy and coconut land extents have been reduced in the buffer zone area while the forest cover and bare land extents have been increased. Scrub lands are appearing in the buffer zone which may be due to non-utilization of these lands. It can be assumed that these scrub lands represent the abandoned cultivated lands that exist at a transition stage.

It is clear that the extent of paddy and coconut cultivated lands have reduced not only in the reservoir area, but also in the buffer zone. Percentage of land use change was calculated using Equation 1 and the values of the extents of land use changed after the dam construction are shown in Table 2.

$$
\% \text { of Land area reduction in the buffer zone }=\frac{L A_{1(\mathrm{i})}-L A_{1(\mathrm{C})}}{T L A}=100 \%
$$

$\mathrm{LA}_{1 \text { (i) }}$ - Extent of land use type 1 before dam construction

$\mathrm{LA}_{1 \text { (a) }}$ - Extent of land use type 1 after dam construction

TLA - Total land extent of the buffer zone

Table 2. Land use of the $100 \mathrm{~m}$ buffer zone before and after construction of the dam

\begin{tabular}{lcccc}
\hline $\begin{array}{l}\text { Type of land use/ } \\
\text { land cover }\end{array}$ & $\begin{array}{c}\text { Extent before } \\
\text { the dam } \\
\text { construction } \\
(\mathbf{2 0 1 0})(\mathbf{h a})\end{array}$ & $\begin{array}{c}\text { Extent after the } \\
\text { dam } \\
\text { construction } \\
\mathbf{( 2 0 1 6 ) ( h a )}\end{array}$ & $\begin{array}{c}\text { Direction of } \\
\text { land use/cover } \\
\text { change }\end{array}$ & $\begin{array}{c}\text { Extent of land } \\
\text { use/ cover } \\
\text { changed (ha) }\end{array}$ \\
\hline Paddy Land & 161.49 & 75.09 & - & 86.4 \\
Forest & 96.54 & 115.40 & + & 18.86 \\
Coconut Lands & 133.49 & 20.54 & - & 112.95 \\
Bare Lands & 16.79 & 94.08 & + & 77.29 \\
Water Tanks & 3.12 & 0 & - & 3.12 \\
Scrub lands & & 106.33 & + & 106.33 \\
\hline Total & 411.44 & 411.44 & & \\
\hline
\end{tabular}


Paddy and coconut land extents have been reduced after the reservoir establishment while forests and bare land extents have increased (Fig. 3). Scrub lands are a new land use pattern that could be observed after the reservoir establishment.

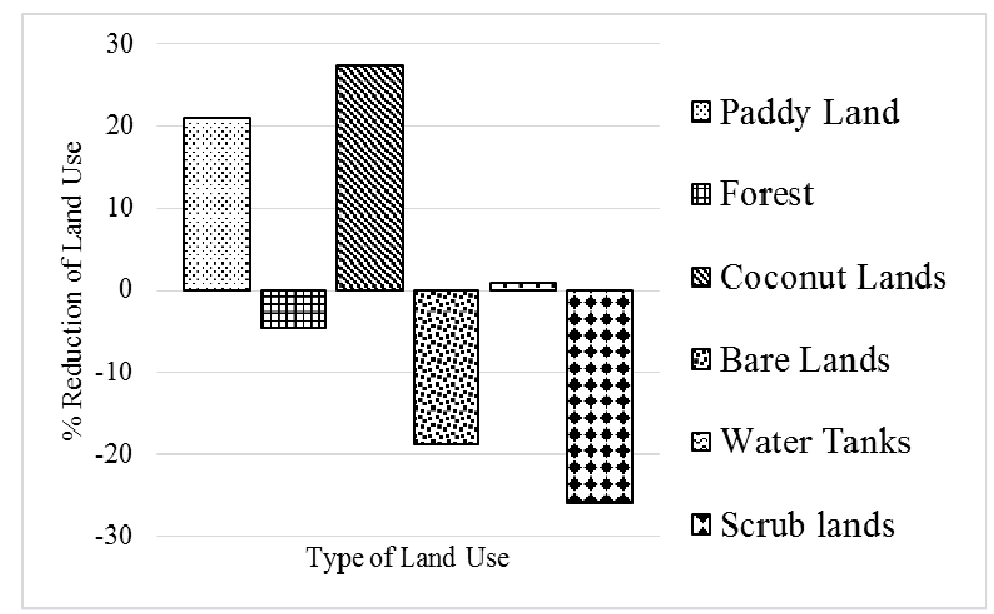

Fig. 3. Percentage changes of land use/ land cover after the dam construction

\section{Impacts of land use changes}

Land use change which occurred as a result of dam construction leads to many adverse impacts on relocated people's lives, not only due to inundation but also due to construction of irrigation canals. For the construction of infrastructure, lands will be acquired by large dam projects (Tilt et al., 2008). This study was only concentrated to the land use change occurred in the inundated area and its buffer zone to identify the possible impacts. There were more than 1000 families who have lived in the inundated area alone, relocated due to Deduru Oya dam construction. Since the major land use types were paddy and coconut lands, no doubt the majority of these population were dependent on agriculture as their main livelihood. According to the Environmental Impact Assessment (EIA) report of Deduru Oya reservoir project, the total area of inundation is mostly cultivated lands. So as the majority of the villagers of the inundation area are farmers, who mostly cultivated paddy and owned home gardens as well as small scale coconut lands (Centre for Environmental Studies UOP, 2003).

The displaced have been resettled in Karuwalgaswewa, Thelahera farm, Polgammana estate, and Peter valley estate. However, one acre of paddy land was given only for those who have resettled in Karuwalagaswewa area. None of others were given lands for cultivation except compensations (Deduru Oya Project Office, 2015). It was aimed to resettle 524 families in Karuwalagaswewa area as they have requested to provide agricultural lands. However, only 149 families have accepted the new lands by the end of 2013 (Deduru Oya Project Office, 2015). Therefore, 149 ha of paddy lands have been distributed among resettled population which is far below the total extent of paddy lands inundated by the project.

According to the analysis (Table 2) there is a considerable drop of paddy and coconut land extents in the buffer zone area. The buffer zone may suffer from elevated water table and may provide undesirable conditions to coconut plantations. Due to land acquisition and resettlement, land owners may leave the area. This also can lead to economic losses and 
social issues. However, increase of forest cover in the buffer zone area can bring ecological and hydrological benefits.

\section{Economic loss of land use change}

Paddy cultivated lands are the major type of land use that was affected by reservoir construction. Since the reservoir was commissioned in 2014, that year was selected as the base year for calculating the economic loss in the study. Total paddy land extent lost after reservoir establishment is 555.76 ha (Table 1 and 2).

The average paddy production in Kurunegala District for 'Maha' season of 2014 and 'Yala' season of 2015 was recorded as $3,425 \mathrm{~kg} / \mathrm{ha}$ and 3,141 kg/ha respectively (Department of Census and Statistics 2015). Since the reservoir inundated 555.76 ha of paddy lands in October 2014, the yield loss can be interpreted considering the cropping intensityof paddyin that relevant year. Accordingly, the loss of paddy yield was estimated as 1,865.4 tons in 2014 'Maha' season and 1,344.1 tons in 'Yala' season due to the reservoir construction (Table 3). The total net revenue loss from inundation of paddy landsdue to the construction of reservoir is estimated asRs. 19.81 million per year.

Table 3. Loss of paddy production and economic loss from paddy per Year

\begin{tabular}{|c|c|c|}
\hline Description & Source/Method & Value \\
\hline Average paddy yield in 'Yala' season $\left(\mathrm{Y}_{\mathrm{y}}\right)$ & $(\mathrm{DoCS})$ & $3,141 \mathrm{~kg} / \mathrm{ha}$ \\
\hline $\begin{array}{l}\text { Average paddy yield in 'Maha' season } \\
\left(\mathrm{Y}_{\mathrm{m}}\right)\end{array}$ & (DoCS) & $3,425 \mathrm{~kg} / \mathrm{ha}$ \\
\hline $\begin{array}{l}\text { Extent of paddy lands loss for reservoir } \\
\left(E_{p}\right)\end{array}$ & Analysis & 555.76 ha \\
\hline $\begin{array}{l}\text { Cropping intensity (Paddy) in 'Yala' } \\
\text { season }\left(\mathrm{CI}_{\mathrm{y}}\right)\end{array}$ & (DoCS) & $77 \%$ \\
\hline $\begin{array}{l}\text { Cropping Intensity (Paddy) in 'Maha' } \\
\text { season }\left(\mathrm{CI}_{\mathrm{m}}\right)\end{array}$ & (DoCS) & $98 \%$ \\
\hline Loss of paddy yield in 'Yala' season $\left(\mathrm{LP}_{\mathrm{y}}\right)$ & $\mathrm{Y}_{\mathrm{y}} * \mathrm{E}_{\mathrm{p}} * \mathrm{CI}_{\mathrm{y}}$ & $1,344.1$ tons \\
\hline $\begin{array}{l}\text { Loss of paddy yield in 'Maha' season } \\
\left(\mathrm{LP}_{\mathrm{m}}\right)\end{array}$ & $\mathrm{Y}_{\mathrm{m}}^{*} \mathrm{E}_{\mathrm{p}} * \mathrm{CI}_{\mathrm{m}}$ & $1,865.4$ tons \\
\hline Price of paddy in 'Yala' season $\left(\mathrm{P}_{\mathrm{y}}\right)$ & DoA & Rs. $35.40 / \mathrm{kg}$ \\
\hline Price of paddy in 'Maha' season $\left(\mathrm{P}_{\mathrm{m}}\right)$ & DoA & Rs. $31.49 / \mathrm{kg}$ \\
\hline $\begin{array}{l}\text { Unit cost including input cost for 'Yala' } \\
\text { season }\left(\mathrm{C}_{\mathrm{y}}\right)\end{array}$ & DoA & Rs. $28.95 / \mathrm{kg}$ \\
\hline $\begin{array}{l}\text { Unit cost including input cost for 'Maha' } \\
\text { season }\left(\mathrm{C}_{\mathrm{m}}\right)\end{array}$ & DoA & Rs. $25.52 / \mathrm{kg}$ \\
\hline Total revenue in 'Yala' season $\left(\operatorname{Tr}_{\mathrm{y}}\right)$ & $\mathrm{Lp}_{\mathrm{y}} * \mathrm{P}_{\mathrm{y}}$ & Rs. 47.59 mil. \\
\hline Total revenue in 'Maha' season $\left(\operatorname{Tr}_{\mathrm{m}}\right)$ & $\mathrm{Lp}_{\mathrm{m}} * \mathrm{P}_{\mathrm{m}}$ & Rs. 58.74 mil. \\
\hline $\begin{array}{l}\text { Total production cost in 'Yala' season } \\
\left(\mathrm{PC}_{\mathrm{y}}\right)\end{array}$ & $\mathrm{LP}_{\mathrm{y}} * \mathrm{C}_{\mathrm{y}}$ & Rs. 38.91 mil. \\
\hline $\begin{array}{l}\text { Total production cost in 'Maha' season } \\
\left(\mathrm{PC}_{\mathrm{m}}\right)\end{array}$ & $\mathrm{LP}_{\mathrm{m}} * \mathrm{C}_{\mathrm{m}}$ & Rs. 47.60 mil. \\
\hline Net revenue loss in 'Yala' season $\left(\mathrm{RL}_{\mathrm{y}}\right)$ & $\mathrm{Tr}_{\mathrm{y}}-\mathrm{PC}_{\mathrm{y}}$ & Rs. 8.67 mil. \\
\hline Net revenue loss in 'Maha' season $\left(\mathrm{RL}_{\mathrm{m}}\right)$ & $\mathrm{Tr}_{\mathrm{m}}-\mathrm{PC}_{\mathrm{m}}$ & Rs. 11.14 mil. \\
\hline $\begin{array}{l}\text { Total income loss in a year due to paddy } \\
\text { land } \operatorname{loss}\left(\mathrm{Lt}_{\mathrm{p}}\right)\end{array}$ & $\left(\mathrm{RL}_{\mathrm{y}}+\mathrm{RL}_{\mathrm{m}}\right)$ & Rs.19.81 mil./yr \\
\hline
\end{tabular}


Source: DoCS - Department of Census and Statistics, 2015, DoA - Department of Agriculture, 2015

Loss of paddy yield for a family make a broad range of impacts since rice is considered as the staple food in Sri Lanka. Food security of these people is under risk due to such losses. Since these people are engaged in agriculture as their major occupation, in addition to losing food security, financial security will also be affected.Although the project provided limited extent of paddy lands to those who have resettled in Karuwalagaswewa area, they are reluctant to cultivate these new lands due to lack of proper irrigation systems and wild elephant attacks.

Coconut is one of major economic crops in Sri Lanka which produced 2, 870 million nuts in 2014 (Department of Census and Statistics, 2015) to bring Rs. 28, 536 million of GNP (Central Bank of Sri Lanka, 2014). According to the Department of Census and Statistics, 394,836 ha of coconut lands were cultivated in 2014 to produce 2, 870 million nuts in Sri Lanka (Department of Census and Statistics, 2015). There were 483.10 ha of coconut cultivated lands lost to the reservoir and the buffer zone according to the analysis. Therefore, total loss of coconut production due to the Deduru Oya Dam construction in the year 2014 can be estimated as 3.51 million nuts (Table 4). Further, economic loss of coconut production was estimated as Rs. 64.60 million/year after the reservoir construction (Table 4).

Table 4. Loss of coconut production and economic loss from coconut per year

\begin{tabular}{|c|c|c|}
\hline Description & Source/Method & Value \\
\hline $\begin{array}{l}\text { Total coconut cultivated extent in } 2014 \\
\text { in Sri Lanka }\left(E_{\text {csl }}\right)\end{array}$ & DoCS & 394836 ha \\
\hline $\begin{array}{l}\text { Total extent of coconut land lost for the } \\
\text { reservoir and buffer }\left(E_{c}\right)\end{array}$ & Analysis & 483.10 ha \\
\hline $\begin{array}{l}\text { Coconut production in Sri Lanka } \\
(2014)\left(C_{p}\right)\end{array}$ & DoCs & 2870 million nuts \\
\hline $\begin{array}{l}\text { Coconut production per unit extent of } \\
\text { land }\left(\mathrm{C}_{\mathrm{pu}}\right)\end{array}$ & $\mathrm{C}_{\mathrm{p}} / \mathrm{E}_{\mathrm{csl}}$ & 0.073 million nuts $/$ ha \\
\hline Total production loss $\left(\mathrm{P}_{1}\right)$ & $\mathrm{C}_{\mathrm{pu}} * \mathrm{E}_{\mathrm{c}}$ & 3.51 million nuts \\
\hline Whole sale price per nut in $2014\left(\mathrm{R}_{\mathrm{p}}\right)$ & Assumption & Rs. 30.00 \\
\hline Cost of Production per nut (COP) & CBSL & Rs. 11.6 \\
\hline Total Revenue loss $\left(\mathrm{R}_{\mathrm{t}}\right)$ & $\mathrm{P}_{1}^{*} \mathrm{R}_{\mathrm{p}}$ & Rs. 105.3 million \\
\hline Total cost of production for $\mathrm{P}_{1}\left(\mathrm{COP}_{t}\right)$ & $\mathrm{P}_{1}^{*} \mathrm{COP}$ & Rs. 40.7 million \\
\hline Net Revenue loss $\left(\mathrm{R}_{\mathrm{n}}\right)$ & $\mathrm{R}_{\mathrm{t}}-\mathrm{COP}_{\mathrm{t}}$ & Rs. 64.60 million \\
\hline
\end{tabular}

The loss of coconut lands cannot only be calculated based on the financial loss. Coconut is an important component of everyday meals in the Sri Lankan culture. Hence, loss of coconut cultivations will have serious consequences on this displaced population. Coconut related small scale industries such as coconut husk and fibre industries prevailing in the Kurunegala district will be affected due to reduction of coconut production as well as to labour shortages because of the relocation of labour force (Centre for Environmental Studies-UOP, 2003).

\section{Economic loss of inundation to individual families}

As stated in the EIA report, $58.89 \%$ of the population in the area did depend on Agriculture as their main occupation among the displaced population (Centre for Environmental StudiesUOP, 2003). Therefore, the number of families engaged in agriculture is estimated to be 624 
since the project displaced 1060 families until 2013. Assuming all these families cultivated paddy and had equal extents of paddy lands, an average revenue loss per family can be calculated by dividing the net revenue loss by the number of families. Using same assumption, revenue loss per family due to loss of coconut production can be calculated. The total loss of annual revenue due to loss of paddy production and coconut production per family is, therefore, estimated as Rs. 144,240(Table 5).

Table 5. Financial loss of individual families due to loss of paddy and coconut production

\begin{tabular}{|c|c|c|}
\hline Description & Method / Reference & Value \\
\hline $\begin{array}{l}\text { Total number of families } \\
\text { displaced }(\mathrm{N})\end{array}$ & (EIA) & 1,060 families \\
\hline $\begin{array}{l}\% \text { of families engaged in } \\
\text { Agriculture }(\%)\end{array}$ & (EIA) & $58.89 \%$ \\
\hline $\begin{array}{l}\text { Number of families } \\
\text { engaged in Agriculture } \\
\left(\mathrm{N}_{\mathrm{a}}\right)\end{array}$ & $\mathrm{N} * \%$ & 624 families \\
\hline $\begin{array}{l}\text { Total income loss in a year } \\
\text { due to paddy land loss per } \\
\text { family }\left(\mathrm{Lf}_{\mathrm{p}}\right)\end{array}$ & $\mathrm{Lt}_{\mathrm{p}} / \mathrm{N}_{\mathrm{a}}$ & Rs. $40,713.60 /$ family/year \\
\hline $\begin{array}{l}\text { Total income loss in a year } \\
\text { due to coconut land loss per } \\
\text { family }\left(\mathrm{Lf}_{\mathrm{c}}\right)\end{array}$ & $\mathrm{R}_{\mathrm{n}} / \mathrm{N}_{\mathrm{a}}$ & Rs. $103,526 /$ family/year \\
\hline $\begin{array}{l}\text { Total income loss in a year } \\
\text { due to both paddy and } \\
\text { coconut land loss }(\mathrm{L})\end{array}$ & $\mathrm{Lf}_{\mathrm{p}}+\mathrm{Lf}_{\mathrm{c}}$ & Rs. $144,240 /$ family/year \\
\hline
\end{tabular}

\section{Impacts of loss of infrastructure}

Loss of roads and infrastructure to the reservoir will make difficulties to the people who live closer to the reservoir by changing the routing activities. According to the EIA report, the impacts on existing infrastructure are very low in this project. There were no schools, hospitals or government holdings in the inundated area (Centre for Environmental Studies UOP, 2003). According to the analysis, total length of affected roads is $11.256 \mathrm{~km}$ which were gravel roads. As the lands which were accessed by these roads go under water, the impact is minimal. However, the level crossing (causeway) on Kimbulwanaoya and the bridge crossing Maho and Dambagolla were inundated, and as a result, people in the nearby area have to face difficulties in transport.

\section{Achievements of the project over the negative impacts}

Right Bank Canal (RBC) of the reservoir is known to be a trans-basin canal connecting Inginimitiya reservoir that carries water to 'Mee Oya' basin from Deduru Oya basin to augment irrigation water supplies to 3715 ha of existing agriculture lands under major/medium irrigation scheme (Irrigation Department, 2013). Left Bank Canal (LBC) is expected to supply water to augment irrigation water supplies through a network of canal system to 2400 ha of paddy lands under minor irrigation systems and to develop 600 ha of new lands in initials reaches of the proposed LBC for Other Field Crops (OFC) cultivation under lift irrigation in Deduru Oya left bank (Irrigation Department, 2013). In addition, a 
hydropower station of $1.5 \mathrm{MW}$ is planned to be established. The project is still at the implementation stage though RBC and LBC have already been established.

It appears that the outcomes of the project will replace the loss of overall agricultural production in the system with a considerable additional improvement. Future research should be directed to evaluate the changes in the downstream land uses to justify the above facts. Still, the affected population will not be happy with overall gain, if their grievances are not properly addressed.

\section{CONCLUSIONS}

Deduru Oya reservoir has inundated about 1170 ha of total land extent in Kurunegala district which consists of $40 \%$ of paddy, $31 \%$ of coconut and $27 \%$ of forest lands. There is a considerable change in land use/ land cover in the reservation area identified as $100 \mathrm{~m}$ from the reservoir boundary. The total economic loss due to inundation of paddy and coconut lands were found to be Rs. $19.81 \mathrm{mil} /$ year and Rs. $64.60 \mathrm{mil} / / \mathrm{year}$ respectively. The economic loss per family as a result of paddy and coconut production foregone is, therefore Rs. 144,240/year. Since their food security and income seemed to have been affected severely due to the reservoir construction, the authorities are required to address the livelihood changes of resettled population and make remedial measures as early as possible.

\section{ACKNOWLEDGEMENT}

This study was carried with the support of a grant from the International Development Research Centre (IDRC), Ottawa, Canada. Their financial support is greatly acknowledged.

\section{REFERENCES}

Aheeyar, M.M.M., Nanayakkara, V.K. and Bandara, M.A.C.S. (2008). Allocation of Water among Different Water-use Sectors in Sri Lanka: Lessons of Experience. HARTI Research Report No: 128, Hector Kobbekaduwa Agrarian Research and Training Institute, Colombo, Sri Lanka.pp 1-4.

Central Bank of Sri Lanka. (2014). Annual Report - National Output, Expenditure and Income, pp 1-32.

Centre for Environmental Studies, UOP (University of Peradeniya). (2003). Environmental Impact Assessment Report, Deduru Oya Reservoir Project, 186p.

Department of Agriculture (2015). Cost of Cultivation of Agricultural Crops, Socio Economic and Planning Centre, Department of Agriculture, Peradeniya.

Department of Census and Statistics (2015). Agriculture and Environmental Statistics Division, Paddy Statistics-2014/2015 'Maha' season and 2015 'Yala' season.

Deduru Oya Project Office. (2015). Irrigation Directors’ Office, Kurunegala.

Di Gregorio, A., Jansen, L.J.M. (2000). Land Cover Classification System, In FAO Corporate Document Repository, pp 10-19. 
European Communities. (2001). Manual of concepts on land cover and land use information systems. 2nd edition. Luxembourg Press Office for Official Publications of the European Communities, pp 13-14.

Hannan, R. (2015). News first. [Accessed on 01.08.2016]. Available at http://newsfirst.lk/english/2015/11/inclement-weather-affects-200000-jaffna-mullaitivukilinochchi-among-areas-affected/118121.

Hoover, R. (2000). Darkness in the Lesotho Highlands - Promises for Power go Unfulfilled [on line]. [Accessed on 01.08.2016]. Available at https://www.internationalrivers.org/resources/darkness-in-the-lesotho-highlands-promisesfor-power-go-unfulfilled-1997.

International Commission of Large Dams. (2015). Role of Dams. [Accessed on 25.07.2016]. Available at http://www.icold-cigb.net/GB/legal.asp.

Irrigation Department (2001). Deduru Oya and Mee Oya Basins Development Project - Pre Feasibility Report, Irrigation Department, Colombo, pp 11-19.

Irrigation Department (2013). Deduru Oya Reservoir Project - Project Benefits. [Accessed on 10.07.2016]. Available at http://daduruoya.blogspot.com/2012/03/project-benefits.html.

Irrigation Department (2014). News and Events - Deduru Oya Reservoir-the Large Irrigation Solution for North Western Province [on line]. [Accessed on 10.07.2016]. Available at http://www.irrigationmin.gov.lk/web/index.php?option $=$ com content\&view $=$ article \&id $=110$ \%3Adeduru-oya-reservoir-the-large-irrigation-solution-for-north-westernprovince \&catid $=45 \% 3$ Anews-a-events $\&$ Itemid $=50 \&$ lang $=$ en

Sahoo, T., Prakash, U. and Sahoo, M. M. (2014). SardarSarovar Dam Controversy- A Case Study. Global Journal of Finance and Management, 6(9), 887 - 892.

Santhiago, M. (2014). News first. [Accessed on 01.08.2016]. Available at http://newsfirst.lk/english/2014/12/flood-warning-effect-deduru-oya-spill-gates-open/69168

Somarathne, P.G.; Jinapala, K.; Perera, L.R.; Ariyarathne, B.R.; Bandaragoda, D.J.; and Making, Ian. (2003). Developing Effective Institutions for Water Resources Management: A Case Study in the Deduru Oya Basin, Sri Lanka, Colombo: International Water Management Institute.

Survey Department. (2014). Departmental Survey Regulations - Chapter X-Reservations [on line]. [Accessed on 2.08.2016]. Available at http://www.survey.gov.lk/surveyweb/Home\%20English/DSR_english.php

Tilt, B., Braun, Y. \& He, D. (2008). Social Impacts of Large Dam Projects: A Comparison of International Case Studies and Implications for Best Practice. Journal of Environmental Management, 1-9.

Wijesundara, C.J., and Dayawansa, N.D.K. (2011). Construction of Large Dams and their Impacts on Cultural Landscape: A Study in Victoria Reservoir and the Surrounding Area. Tropical Agricultural Research. 22(1), 211 - 219. 
WijethungaBandara, T.W.M.T. (2013). Changes in Land Use Systems and their Consequences: A Case Study on Kothmale Oya Catchment. Social Science and Humanities Review. 01, 29 - 74. 